パルプ・紙特集

\title{
世界初のインダストリアル・プラットフォーム システムによるパルププラント
}

中 野弘

\section{1. 概 要}

造船枋よび重機械,プラントの総合メーカーである当社 は 53 年 1 月.ブラジルの農業，森林資源開発会社である

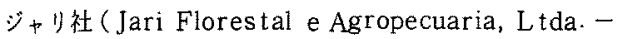
米国届指の海運会社ユーバース タンクシップス社の子 会社）に総額約 600 億内に及ぶ世界でも初めてのインダ ストリアル・プラットフォーム システムによるパルプ プラントの引港しを完了した。

この工事位, $750 \mathrm{t} / \mathrm{d}(260,000 \mathrm{t} / \mathrm{y})$ という一系列と しては世界最大級の晒クラフトパルププラントを2 2 隻の 巨大なプラットフォーム上に建設するというもので，プ ラットフォームの建造から所要機器の設計，製作，調達， プラットフォーム上への据付までの一切を当社が行った。 プラントを構成する諸機器, 配管等は大型のブロックに 組んでプラットフォームに塔載され，造船所内でできる だけ多くの機器につき試連転を完了した後，FOBべー スで客先へ引䉀された。以後プラントサイトである南米 アマゾン流域まで曳航され，サイトでは水位差を利用し て河岸の陸地上に固定してプラントとして運転される予 定である。

このようなアイディアは、最近世界のコンサルタント． エンジニアリング会社，プラントメーカー，造船所など から原々公表されているが，

（1）インフラストラクチャ一の整備されていない地域 にもプラント建設が可能。

（2）工期が短縮できる。などの利点からして今後開発

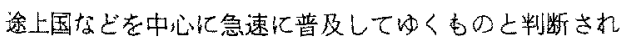
る。

World's First Pulp Plant Built on "Industrial Platform System"

HIROSHI NAKANO

Ishikawajima-Harima Heavy Industries Co., Ltd. Section Manager of Pulp and Paper Planning Dept., Tsukuda 2, Chuo-ku, Tokyo, Japan

石川葛播磨重工業株式会社

慗絓機械計画部 基本設計課長
2. プロジェクトの背景

パルププラントの社文主であるジャリ社では, 1960 年 代の後半にブラジル・アマゾン河の支流ジャリ河流域の ムングハ地区に約 300 万エーカ一の土地を確保し，ここ にメライナ(Hard wood) 拉よびカリビアンパイン（Sof t wood）在植林すると共に，同地域で水田の開拓や牧畜を 行うなよ総合的な畜産，農業，森林事業を営んできた。 植林された樹木はいずれす7〜8年で成木に達するとい うきわぬて成長の早い森林凟䝠であるがパルプの原料上 して利用する場合, 成木汇達した時期の前後が伐採传最 適な時期とされている。ジャリ社ではての菻林資崲が伐 操適正期を迎元るにあたってその利用方法を種々検討し たが、パルプにして出荷するのが最もメリットが大きい との判断に達した。

しかし問題はパルプ工場の建設。建設予定地点はアマ ゾン河口のベレムから約 $400 \mathrm{~km}$, ほ结赤道直下住置す る高温，多雨，多湿地带である。サイトにはジャリ社の 農業，森林事業们従事する人達加居住する人口約 4,000 人の居住地域がすでにできあがっているが，交通手段は ベレムからの専用機の利用か，川船の利用加しかない。 屯ち万ん大かかからプラント建設比必要な機材や大型機 器の陸揚げ運搬飞必要な港湾施設，道路などのいわゆる インフラストラクチャ一は米整備の状態にある。ジャリ 河は，この召であ川幅が約 $600 \mathrm{~m}$ ほどあり，諸資材搬入 のための水路としては有効だが，雨期，乾期の水位差が はげしいため重量物の年中を通してのコンスタントな荷 役には種々の困難が予想された。また熟練労働者をプラ ントの建設期間中を通してサイトにキープするのもコス 卜がかかるし困難が伴う。プラントの建設を初期のスケ シュールどうり進行させ得るかどうかを䀣念される原因 がそろいすきている一方，プラントは森林資源の伐採適 正期までに早急に完成させる必要があった。

3. インダストリアル・プラットフォーム・ システムのスタディとその採用

とうしたプラント建設を困難上する諸条件下で所要の 
パルププラントをスピーディかつスケジュールどうりに 建設するには，プラントの主要部分をエンジニアリング 体制や設備, 熟練労㗢力之あ十分任之とのった工場内で 製作，据付してしまうというインダストリアル，プラッ トフォーム、システムがきわめて有効である。

注文主ジャリ社の親会社であるユニバース・タンクシ ップス社と当社とは船舶の建造を通じて長い間の取引 関係もあり，両社間ではインフラストラクチャー未整 備地域におけるプラント建設方法之して同方式の適合 性が以前加話し合われていた。そのような関係からて のパルププラントのプロジェクトはまずフィージビリテ 1 スタディという形で IHI に持ち込まれ，以後ジャリ 社, IHIのジョイント スタディの形でプロジェクト が進行した。我々のスタディの結果は次の通りであっ た。

（1）プラントの主要部分を当社の造船所内でプラット フォーム上に塔載して現地に电航する。

（2）現地ではあらかじめプラント設置予定のサイトに 掘割を建設し，基礎パイルを打ち込んでおき，乙の基礎 上にプラットフォームを浮かせながら導き入れ，後は水 を抜いてプラットフォームを甚礎上任固定する。

（3）ての方法を採用するてとによりプラントの建設期 間を 1 1.5 年短縮するてとが可能であるとともに，プラ ント運転開始時期の正確な設定が容易である。

（4）プラント建設コストの面であ通常のプラント建設 亿比へ 15 20\%程度削減できる。

当初は水処理設備などもインダストリアル・プラット フォーム方式で完成した状態のむのを現地に搬入するて とも検討したが，建設期間や経済性の点でさしたるメリ ットが期待できないため，パルプ製造プラントの主要部 分にとどめた。

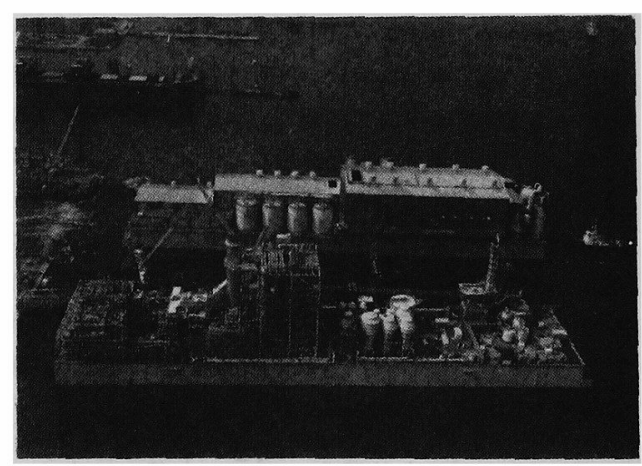

図 1

\section{4. プラントの概要}

ジャリ社向けに建設されたパルププラントはプラント の主要部分を 2 隻のプラットフォームに分割して塔載し た。

(1) パルププラント・プラットフォーム

パルプ製造の主プロセス機器を塔載するパルププラン ト・プラットフォームは, 長さ $230 \mathrm{~m}$ ，幅 $45 \mathrm{~m}$, 総高さ $58 \mathrm{~m}$, というサイズでプラットフォーム内には, 蒸解設 備, 洗浄設備, 漂白設備, 精選設備, パルプマシン・シ 一トドライヤ，包装設備などの機器が塔載されている。

蒸解： 8ーバッチダイジェスタ

洗浄：3ードラムウオッシャー

漂白： $\quad 5$ 段 $\mathrm{d} / \mathrm{c}-\mathrm{E}-\mathrm{D}-\mathrm{E}-\mathrm{D}$

パルプマシン： IHI-BC型

仕上幅 $\quad 7200 \mathrm{~mm}$

シートドライヤ：SFドライヤ

包装設備：〔ベールおよびユニット

製品：日晒クラフトシートパルプ

（2）パワープラント・プラットフォーム

一方，パルプを生産するために必要な動力や蒸気を供 給するとともに, パルプ洗浄排液 (ブラックリカー) 中の 苛性ソーダなどの薬品を回収し再使用するための装置を 持つパワープラント プラットフォームには，2つの動 カボイラ, タービン発電機, 回収ボイラ. 黒液濃縮装置 苛性化装置, キルンなどが塔載されている。プラットフ オームのサイズは, 長さ $220 \mathrm{~m}$, 幅 $45 \mathrm{~m}$, 総高さ $66 \mathrm{~m}$ である。

動力ボイラ： $2-140 \mathrm{t} / \mathrm{h}$

タービン発電機 : $55000 \mathrm{~kW}$

回収ボイラ： $208 \mathrm{t} / \mathrm{h}$

黒液濃縮装置 : 6 重効用

キルン： $\quad 284 \mathrm{t} / \mathrm{d}, 4 \mathrm{~m} \times 89 \mathrm{~m}$

5. ブロックエ法の採用

インダストリアル プラットフォーム システムの実 際の建造にあたってあ造船技術がフルに活用される。造 船の場合, 船体を構成するブロックをあらかじめ工場建 屋内ないしドックや船台仁隣接したヤードで製作してし まい，これを順次塔載しながら船体の建造を進めていく ブロック建造法が採用されているが, 機器が何層にもさ くそうする機関室まわりの建造には，とのブロック工法 をさらに進歩させたユニット艤装と呼ばれる工法が採用 されている。多数の機器類を配置されるべき区画に従っ てまとめ，これらを所定の配管などを含めてあらかじめ いくつかのユニットにしてしまった上で，船体上に塔載 


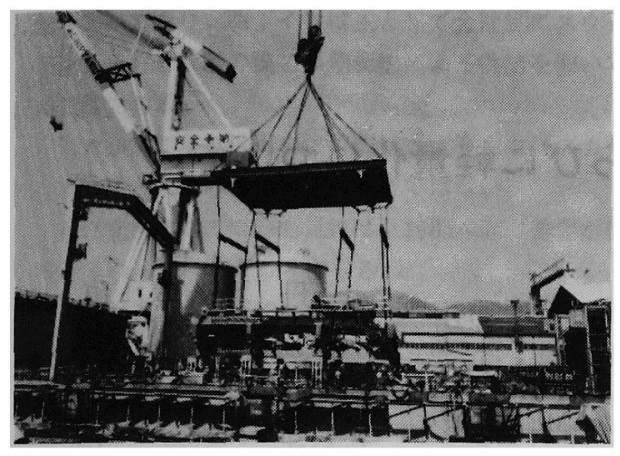

困 2

していくという方法である。 今回のパルププラントの建造にあたっては, IHI の各 工場や関連メ一カーで製作された機器は，スケジュール に従って当社呉造船所に搬入され，造船所の建造ドック 内で先述の工法により船体部分とあわせてプラントにま とめあげられた。造船所には大型の機器やブロック ユ ニットを運搬, 塔載するのに十分な設備や熟練技能者が そろっており，建造上で生じる細加い問題を解決してい 〈ためのエンジニアリング・スタッフや検査, 工程管理 のためのスタッフも十分なので, 工期どうりに品質のよ いプラントを建造するととができるわけである。

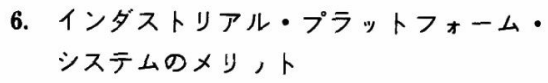

（1）複雑なプラントの工場内製作，据付が可能である。 通常各種のプラントの現地工事にあたっては様々な機材 や熟練労㗢者が必要であり，また建設過程でのトラブル を適確に処理するため，ある程度のエンジニアリング機 能むサイトに持たなくてはならいが，インダストリアル ・プラットフォーム システムの場合, これら設備、人 員，技術とも完備した工場内でプラント建設工事のほ之 んどを仕上げてしまうことができる。

（2）従って, 自然条件の悪い地域や, インフラストラ クチャーの未整備の地域にも，開発の二ーズにしたがっ て先行して，プラントを建設するととができる。
（3）製作，据付精度がきわめて高くなる。

（4）プラントサイトの気象条件や道路，港湾などの整 備度によって工事スケージュールが左右されることが少 ないので工期の大幅な短縮も可能である。

（5）自航式亡すれば, 原料の供給源の変化にしたがい 移動させることも可能である。

その他にも建設期間の短縮，建設コストの削減は建設 資金の金利にも大きくかかわってくるし，プラントのラ ンニングコストにも大きく影響してくる。てれらを節約 できるだけであそのメリットは大きいといえる。

\section{7. 今後の展望}

インダストリアル・プラットフォーム システムとい うアイディアは決して新しいあのではない。昔からある 蟹工船や鯨工船むその一種ということができよう。しか し, 従来のとの種システムが一部に特殊な例外があると はいいながら，主として，水産資源の加工などを中心と したものであったのに対し，同システムはこれまで陸上 設置が常識とされてきた紙パルプ、発電, 海水淡水化, 石油精製などあらゆる産業プラントに適用される点が, 従来と大きく異なっている。

またてれまでに述べた特徵からしてインダストリアル プラットフォーム システムは，工業化が急務な開発途 上国にとってはきわめて魅力的なものといえよう。てれ らの国々では工業化の資金を捻出するためにあ，持てる 資源を一日でも早く商品化する必要がある。ジャリ社向 けのパルププラントの場合, ブラジルの輸出産品開発計 画，およびアマゾン開発計画のためにあ、同プラントの 早期稼動が望ましいとして，同国政府の承認がなされた ものである。

一方，先進諸国においても工期短縮，建設コスト削减 という目的のほかにプラント建設用適地の狭险化, 環境 問題を中心とする立地上の制約などから今後インダスト リアル・プラットフォーム システムが順次採用されて いくことになろう。インダストリアル・プラットフォー ム システムはあちろん万能ではない。しかしその多く の特徴からして今後世界各国沈おて着々と増加し，プ ラント建設方法に新しい一つの流れをつくり出すものと 期待している。

（昭和 53 年 3 月 3 日受理） 